\title{
INTERMEDIATE ENDEMICITY OF HEPATITIS A VIRUS INFECTION IN RURAL SETTLEMENT PROJECTS OF SOUTHWEST GOIÁS, BRAZIL
}

\author{
Raquel Silva PINHEIRO', Lyriane Apolinário de ARAÚJO², \\ Karlla Antonieta Amorim CAETAN0 ${ }^{1}$, Marcos André de MATOS ${ }^{1}$, \\ Megmar Aparecida dos Santos CARNEIRO² and Sheila Araújo TELES 1
}

Received 20/1/2015 Accepted 1/4/2015

\begin{abstract}
Background - Rural populations present an elevated risk of exposure to hepatitis A virus. Objective - The objective of this study was to estimate the prevalence and risk factors associated with hepatitis A virus infection among residents of rural settlement projects of southwest Goiás, Central Brazil. Methods - A total of 466 residents were interviewed and tested for the detection of anti- hepatitis A virus antibodies by ELISA. Results - The global prevalence of anti- hepatitis A virus was $82.2 \%$. In individuals aged 5-9 years and 10-19 years, the prevalence was $15 \%$ and 58.8\%, respectively. Persons in the 10-19 age group, with a history of life in encampments, with more than five people per residence consuming well water, were predictors for exposure to hepatitis A virus. Conclusion - Our results suggest that the hepatitis A virus endemicity in rural settlements in southwest Goiás similar to that found in the urban population of the Midwest Region, confirming the implementation of universal hepatitis A vaccination in children.

HEADINGS - Hepatitis A. Prevalence. Squatter settlements.
\end{abstract}

\section{INTRODUCTION}

Infection with hepatitis A virus (HAV) is a self-limiting disease, with a strong public health impact, resulting in morbidity and costs related to hospitalizations ${ }^{(1,3)}$. The distribution of this infection is worldwide, occurring more frequently in populations of less economically developed regions that have little education and poor hygienic and sanitary conditions $\mathbf{s}^{(9)}$.

In Brazil, approximately 30 million people live in rural areas, accounting for $15.6 \%$ of the general population $^{(11)}$. These communities represent the highest rates of infant mortality, incidence of endemic diseases, poor health and illiteracy ${ }^{(2)}$.

Residents of rural settlement projects represent an emerging population with unique characteristics and a historical struggle for reintegration into society, in concert with and in conquest of the land; faced with adverse conditions for life and health, as well as the diverse cultures that have come together for a single purpose ${ }^{(13)}$. There are over a million such families settled in the country; many living under unfavorable living conditions that facilitate the spread of microorganisms transmitted by food and water, such as HAV.
Common problems are lack of drinking water, use of rudimentary drains, and inadequate disposal of waste that negatively impact water and soil quality.

A population-based investigation showed an intermediate endemicity for hepatitis A in the capitals of Midwestern Brazil, with prevalence ranging from $32.3 \%$ to $56 \%$ among individuals aged 5-9 years and 10-19 years, respectively ${ }^{(4)}$. However, these data reflect only the urban population, further evaluation of rural populations is necessary. The aim of this study was to estimate the prevalence and risk factors associated with HAV infection among residents of rural settlement projects in Southwest Goiás, Central Brazil.

\section{METHODS}

From May to July 2011, 466 individuals were recruited from seven rural settlement projects (Santa Rita, Rio Claro, Guadalupe, Terra e Liberdade, Romulos Souza Pereira, Lagoa do Bonfim, and Três Pontes) in the municipalities of Jataí and Perolândia, in Midwestern Brazil.

All were interviewed about sociodemographic

${ }^{1}$ Faculdade de Enfermagem, Universidade Federal de Goiás, Goiânia, GO; ${ }^{2}$.Instituto de Patologia Tropical e Saúde Pública, Universidade Federal de Goiás, Goiânia, GO Brasil.

Correspondence: Sheila Araujo Teles. Rua 227 s/n, Setor Leste Universitário. CEP: 74080-605 - Goiânia, GO, Brasil. E-mail: sheila.fen@gmail.com 
characteristics and potential risk factors for HAV infection. From each participant, $10 \mathrm{~mL}$ of blood were collected, and blood samples were tested for total anti-HAV (IgM and $\operatorname{IgG}$ ), using the commercial reagents Bioelisa HAV (Biokit SA, Barcelona, Spain).The study was approved by the Research and Ethics Committee of the Federal University of Goias, protocol n. 127/2010.

Data analysis of the interviews and serologic tests used the STATA statistical software version 10.0. Prevalences were calculated with a confidence interval of $95 \%(95 \%$ CI). Prevalence ratios $(95 \% \mathrm{CI})$ were estimated to assess the level of association between exposure to HAV (anti-HAV) and potential risk factors. Variables with a $P$ value $<0.10$ were included in the Poisson Regression model. Chi-square and Fisher exact tests were used to test differences between proportions.

\section{RESULTS}

Nearly half of the population was male (52.1\%). The median age was 41 years (minimum: 2; maximum: 93 ), and monthly income of approximately \$210.00 USD (minimum: 39; maximum: 3460, USD, approximately). Most are self-de- clared mixed race $(60.1 \%)$, were married $(57.9 \%)$ and had a maximum of eight years of formal schooling $(82.5 \%)$.

Of the 466 residents investigated, $82.2 \%$ (95\% CI: 78.5 to 85.5) were positive for total anti-HAV. No resident under 5 years of age showed evidence of HAV exposure. By contrast, $98.2 \%$ (337/343) of subjects aged over 20 years had already been exposed to the virus. From 5 years to 9 years, (6/40) and 10-19 years (40/68) the anti-HAV prevalence was $15 \%$ (95\% CI: 7.1 to 29.1 ) and $58.8 \%$ (95\% CI: 47.0 to 69.7), respectively (Figure 1). The analysis of potential risk factors for exposure to HAV was performed in the subgroup 5-19 years and found that the age group of 10-19 years $(\mathrm{OR}=1.34)$, prior experiences in camps $(\mathrm{RP}=1.10)$, home of more than five people $(\mathrm{PR}=1.18)$, and consumption of well water $(\mathrm{PR}=1.27)$ were predictors of exposure to HAV (Table 1).

\section{DISCUSSION}

In this study, surprisingly, prevalence of HAV infection in the age group 5-19 years suggests intermediate endemicity for hepatitis A among residents of rural settlement projects

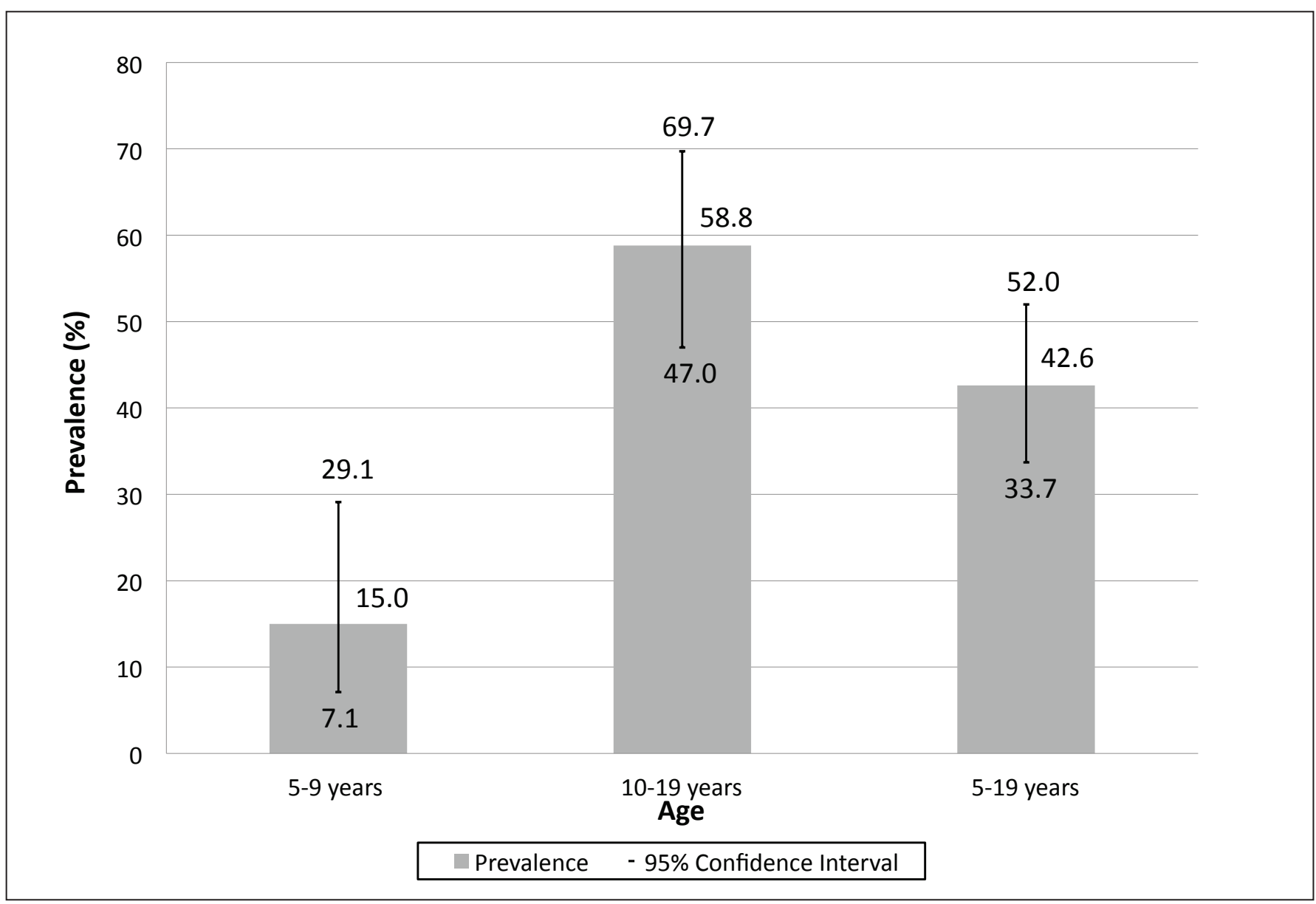

FIGURE 1. Global prevalence of anti-HAV among residents of rural settlement projects in Midwestern Brazil 
TABLE 1. Risk factors associated with anti-HAV among residents of rural settlement projects in Midwestern Brazil

\begin{tabular}{|c|c|c|c|c|c|}
\hline Risk factor & $\begin{array}{c}\text { Anti-HAV } \\
\text { Positive/total }\end{array}$ & PR $_{\text {Crude }}($ IC 95\%) & $P$ & $\mathbf{P R}_{\text {Adjusted }}(\mathrm{IC}$ 95\%) & $P$ \\
\hline \multicolumn{6}{|l|}{ Sex } \\
\hline Female & $19 / 46$ & 1.00 & & 1.00 & \\
\hline Male & $27 / 62$ & $1.02(0.89-1.16)$ & 0.82 & $1.03(0.92-1.16)$ & 0.56 \\
\hline \multicolumn{6}{|l|}{ Age (year) } \\
\hline $5-9$ & $6 / 40$ & 1.00 & & 1.00 & \\
\hline $10-19$ & $40 / 68$ & $1.38(1.22-1.60)$ & 0.00 & $1.34(1.22-1.54)$ & $<0.001$ \\
\hline \multicolumn{6}{|l|}{ Education (years) } \\
\hline$\leq 9$ & $40 / 99$ & 1.00 & & 1.00 & \\
\hline$>9$ & $6 / 9$ & $1.19(0.97-1.45)$ & 0.09 & $1.10(0.89-1.37)$ & 0.36 \\
\hline \multicolumn{6}{|c|}{ Prior experiences in camps } \\
\hline No & $19 / 52$ & 1.00 & & 1.00 & \\
\hline Yes & $27 / 56$ & $1.09(0.95-1.24)$ & 0.22 & $1.10(1.11-1.34)$ & 0.004 \\
\hline \multicolumn{6}{|c|}{ Number of people in the household } \\
\hline$\leq 5$ & $30 / 76$ & 1.00 & & 1.00 & \\
\hline$>5$ & $16 / 32$ & $1.07(0.93-1.24)$ & 0.31 & $1.18(1.05-1.33)$ & 0.007 \\
\hline \multicolumn{6}{|c|}{ Source of water consumed } \\
\hline Lake/river/dike & $38 / 97$ & 1.00 & & 1.00 & \\
\hline Wells & $8 / 11$ & $1.24(1.05-1.47)$ & 0.01 & $1.27(1.03-1.55)$ & 0.02 \\
\hline \multicolumn{6}{|c|}{ Drinking water treatment } \\
\hline Filtered & $35 / 81$ & 1.00 & & 1.00 & \\
\hline No filtered & $11 / 27$ & $0.98(0.92-1.06)$ & 0.69 & $0.97(0.85-1.10)$ & 0.63 \\
\hline
\end{tabular}

HAV: hepatitis A virus; PR: Prevalence Ratio; 95\% CI: 95\% confidence interval; Adjusted for sex, age, education, prior experiences in camps, number of people in the household, source of water consumed and drinking water treatment.

in Goias. Still, the age group 10-19 years (adjusted PR=1.34; $95 \%$ CI: 1.22 to 1.54 ) was predictive of HAV infection among the rural residents investigated, confirming the population-based study conducted in the Brazilian capitals, which showed a larger force of HAV infection in adolescents in areas of intermediate endemicity ${ }^{(5)}$. This similarity may also reflect improvement of sanitary conditions in rural populations as the infection shifts to older age groups.

During the initial process of land occupation, many individuals live on the sides of highways in improvised tarp tents, without electricity or sanitary facilities. Furthermore, the use of black tanks (basic, often open-pit septic tanks) is common in camps, which compromises the quality of water and soil, facilitating the spread of pathogens, especially fecal-oral transmission. These unfavorable conditions probably contributed to the findings of this study, given that the settlers who lived in camps reported having had $20 \%$ more risk of exposure to HAV.

As observed by other authors ${ }^{(8,10,14)}$, living environment clusters were predictive of positivity for anti-HAV. In the settlement projects investigated, individuals who reported more than five people living in the same household had almost a $20 \%$ risk of being anti-HAV positive (RP:1.18; $P=0.007$ ). In households of large families, particularly children, the spread of HAV is facilitated, since the vast majority when exposed to the virus develops asymptomatic infection, serving as a silent source of virus for family and community ${ }^{(12)}$.

Settlers who reported drinking well water had 1.27 times higher risk of exposure to HAV. Much of the water consumed on farms comes from wells dug into the surface, which are located very close to ditches or areas occupied by animals ${ }^{(6)}$. Moreover, in these settlements, in most households, the water of the wells was not channeled, and this has been associated with positivity for anti-HAV ${ }^{(4)}$.

Although a significant association was not found between HAV positivity and consumption of filtered water, we observed a higher prevalence among participants who filtered their water. This result was also identified among similar populations in the Brazilian Amazon Basin ${ }^{(15)}$ and can imply that although water filters are available, lack of knowledge of correct maintenance and cleaning of these tools affect the quality of water consumed.

The convenience of sampling and the choice of total anti-HAV as a marker of exposure to HAV are limitations to this study. However, the anti-HAV total has been largely used in epidemiological investigations to estimate the prevalence of HAV, though it does not allow distinguishing between acute and resolved infection and immunization ${ }^{(7)}$. 


\section{CONCLUSION}

These results suggest an intermediate HAV endemicity in rural settlements, with increased risk of infection among adolescents and the consequent increase in number of individuals susceptible to disease. These results confirm the deployment of hepatitis A vaccine in infant immunization schedules, including the rural population. However, effective implementation of public policies directed towards the development and/or improvements in water supply and sewage systems in improvised communities is imperative, in order to reduce morbidity and mortality caused by waterborne diseases.

\section{Authors' contributions}

The authors state that there was effective participation of all authors mentioned in this work. Substantial contributions to the conception or design of the work: Pinheiro RS, Matos MA; Caetano KAA, Araújo LA, Carneiro MAS and Teles SA. Acquisition of data: Pinheiro RS, Matos MA, Caetano KAA, Araújo LA. Serological analysis: Carneiro MAS. Analysis and interpretation of data for the work: Pinheiro RS and Teles SA. Drafting the work or revising it critically for important intellectual content: Carneiro MAS and Teles SA. Final approval of the version to be published: Carneiro MAS and Teles SA.

Pinheiro RS, Araújo LA, Caetano KAA, Matos MA, Carneiro MAS, Teles SA. Endemicidade intermediária da infecção pelo vírus da hepatite A em projetos de assentamentos rurais do Sudoeste de Goiás, Brasil. Arq Gastroenterol. 2015,52(3):200-3.

RESUMO - Contexto - Populações rurais apresentam um risco elevado de exposição ao vírus da hepatite A. Objetivo - O objetivo deste estudo foi estimar a prevalência e fatores de risco associados à infecção pelo vírus da hepatite A em assentados da região Sudoeste de Goiás, Brasil Central. Métodos - Um total de 466 assentados foi entrevistado e testado para deteç̧ão de anticorpos anti vírus da hepatite A por ELISA. Resultados - A prevalência global de anti vírus da hepatite A foi de 82,2\%. Em indivíduos de 5-9 anos e 10-19 anos, a prevalência foi de 15\% e 58,8\%, respectivamente. Faixa etária de 10-19 anos, antecedentes de vida em acampamento, mais de cinco pessoas por domicílio e consumir água de poços foram preditores de exposição ao vírus da hepatite. Conclusão - Nossos resultados sugerem que a endemicidade do vírus da hepatite em assentamentos rurais do Sudoeste de Goiás é semelhante a encontrada na população urbana da Região Centro-Oeste, ratificando a implementação da vacinação universal contra hepatite A em crianças.

DESCRITORES - Hepatite A. Prevalência. Assentamentos rurais.

\section{REFERENCES}

1. Arteaga-Rodríguez A, Carrasco-Garrido P, de Andrés AL, de Miguel AG, Santos J, Jiménez-García R. Changes in the epidemiology of hepatitis A in Spain (20052008): trends of acute hepatitis A hospitalizations, comorbidities, and costs associated with the hospitalization. Eur J GastroenterolHepatol.2010;22(11):1284-9.

2. Brasil. Ministério da Saúde. Secretaria de Gestão Estratégica e Participativa. Política Nacional de Saúde Integral das Populações do Campo e da Floresta. Brasília (DF); 2011.

3. Brasil. Ministério da Saúde. Secretaria de Ciência, Tecnologia e Insumos Estratégicos. Vacina de hepatite A. Brasília (DF); 2012

4. de Alencar Ximenes RA, Martelli CM, Merchán-Hamann E, Montarroyos UR, Braga MC, de Lima ML et al. Multilevel analysis of hepatitis A infection in children and adolescents: a household survey in the Northeast and Central-west regions of Brazil. Int J Epidemiol.2008;37(4):852-61.

5. de Alencar Ximenes RA, Martelli CMT, Amaku M, Sartori AMC, de Soarez PC, Novaes HMD et al. Modelling the force of infection for hepatitis A in an urban population-based survey: a comparison of transmission patterns in Brazilian macro-region. PLoSOne. 2014;9(5):e94622.

6. do Amaral LA, Nader Filho A, Rossi Junior OD, Ferreira FL, Barros LS. [Drinking water in rural farms as a risk factor to human health]. Rev Saúde Pública. 2003;37(4):510-4.

7. Fiore AE, Wasley A, Bell BP. Prevention of hepatitis A through active or passive immunization: recommendations of the Advisory Committee on Immunization Practices (ACIP). MMWR Recomm Rep. 2006; 55(RR-7):1-23
8. Halicioglu O, Akman SA, Tatar B, Atesli R, Kose S. Hepatitis A seroprevalence in children and adolescents aged 1-18 years among a low socioeconomic population in Izmir, Turkey. Travel Med Infect Dis. 2012;10(1):43-7.

9. Jacobsen KH, Wiersma ST. Hepatitis A virus seroprevalence by age and world region, 1990 and 2005. Vaccine. 2010;28(41):6653-7.

10. Markus JR, Cruz CR, Maluf EMCP, Tahan TT, Hoffmann MM. Seroprevalence of hepatitis A in children and adolescents. J Pediatr (Rio J). 2011;87(5) 419-24.

11. Ministério do Planejamento, Orçamento e Gestão. Instituto Brasileiro de Geografia e Estatística (IBGE). Censo Demográfico 2010. Brasília (DF): Instituto Brasileiro de Geografia e Estatística (IBGE); 2010.

12. Nesti MM, Goldbaum M. Infectious diseases and daycare and preschool education. J Pediatr (Rio J). 2007;83(4):299-312.

13. Scopinho RA. Em busca de "elos perdidos" Projeto de Assentamento e modos de identificação entre trabalhadores rurais assentados. Cad Psicol Soc Trab. 2009;12:257-70.

14. Vitral CL, Ospina FL, Artimos S, Melgaço JG, Cruz OG, de Paula VS et al. Declining prevalence of hepatitis A virus antibodies among children from low socioeconomic groups reinforces the need for the implementation of hepatitis A vaccination in Brazil. Mem Inst Oswaldo Cruz. 2012;107(5):652-8.

15. Vitral CL, da Silva-Nunes M, Pinto MA, de Oliveira JM, Gaspar AM, Pereira RC, et al. Hepatitis A and E seroprevalence and associated risk factors: a community-based cross-sectional survey in rural Amazonia. BMC Infect Dis. $2014 ; 14: 458$. 